\title{
Imperative for the Future Human Happiness (Project of Volodymyr Vynnychenko)
}

\author{
Nataliia Zhukova \\ Dr. habil. in Cultural Studies, Associate Professor, Head of the Department \\ of Graphic Art of Institute of Printing and Publishing of National Technical University \\ of Ukraine "Igor Sikorsky Kyiv Polytechnic Institute" (Kyiv, Ukraine) \\ E-mail: natnina1970@gmail.com \\ https://orcid.org/0000-0001-5710-2372
}

The article is devoted to the moral reflections of Volodymyr Vynnychenko (1880-1951), a Ukrainian writer, playwright, first prime minister, a staunch supporter of political freedom of the Ukrainian state. Vynnychenko's moral searches are basedon the actualization of spiritual love,erotic and sexual relationships as a problem of happiness, self-improvement as the means of activating the moral principle of "honesty with oneself," as well as the pursuit of social justice, which in general provide the exactbalance and harmony the writer so sought to achieve, connect a person with other people, while maintaining at the same time one's freedom and individuality.

The logic of forming a moral conceptcompares the ideas of "concordism" by Volodymyr Vynnychenko and Albert Schweitzer's (1875-1965) concept of "reverence for life." Arguably, unlike Vynnychenko, Schweitzer sought the highest philosophical truth, first of all, to turn it into realityhimself, to achieve a spiritual connection with the Universethrough the ethics of reverence for life. For Schweitzer, to become moral means to become truly thinking, to do good for the afflicted is an internal need, the leitmotif of his whole life.

Keywords: themoral position, Volodymyr Vynnychenko, Albert Schweitzer, eudaimonism, concordism, balance, new ethics, honesty with oneself, will, morality, reverence for life

Received: October 4, 2019; accepted: October 25, 2019

Future Human Image, Volume 12, 2019: 143-150

https://doi.org/10.29202/fhi/12/13

\section{Introduction}

It is well-known that historical chronology is conditional: a century, a decade, the beginning or end of a day, is determined not only by a date accepted as a reference boundary but also by the "face of an era," meaning those personalities whose thoughts and actions more or less influenced the civilizational processes. At the same time, one should considerthe total number of secondary events at certain intervals. The history of each nation is a multitude of alternatives: the intellectual willpower of a person determines choosing among them, which also depends on

(C) Zhukova, Nataliia, 2019 
chance or unpredictability manifesting itself in the dynamics of the civilizational movement. As Yuri Lotman rightly notes, "history is not a single-linear process, but a multifactor flow. When the bifurcation point is reached, the movement seems to stop as if thinking over the path to go" [Lotman, 1988: 4].

To our deep conviction, the Lotman's idea, regarding the non-linearity of the historical process and its ability of "stopping" to think about the choice of a path, fully corresponds to the life and career of Volodymyr Kyrylovych Vynnychenko (1880-1951), whose life and work coincide with a period marked by moral catharsis that caused both the tragedy of the individual and the tragedy of the act.

\section{Urgency Of The Problem}

It is noteworthy and no accident that numerous works are devoted to the analysis of Vynnychenko' since, as Gregory Kostyuk rightly notes, "Volodymyr Vynnychenko is the first and only among Ukrainian writers of the twentieth century, whose works even before the 1917 revolution were translated into many languages. His dramas, short stories and novels (The Lie, The Black Panther and the Polar Bear, TheSin, The Law, Honesty with Oneself, The Testament of the Fathers, Equilibrium, Idols, I Want!, Notes of Pug-nosed Mephistopheles, The Tramp, The Talisman, The New Commandment, etc.) were translated and published in different languages of the world often from manuscripts, even before publication in Ukrainian language" [Kostyuk, 1980: 23-24].

Thus, the writer's work could not but become the object of analysis and discussion. The problems of "moral philosophy", being, as a rule, in the form of "moral provocations", and widely represented in Vynnychenko's work, were of interest to his contemporaries, among them were Maxim Gorky, Anatoly Lunacharsky, Ivan Franko, Pavlo Khristyuk, etc. Despite this, from the beginning of the 1930s to the end of the 1980s in the USSR, his works were terra incognita.

Scientists of the Ukrainian diaspora, who actively worked in the USA, Canada, and also in some European countries, carried out the attempts to comprehend various sections of the heritage of both Vynnychenko as the writer, and Vynnychenko as the politician. Even until nowadays, however, it has not yet been possible to reconstruct an integral model of Vynnychenko's heritage. The activities of Vynnychenko as the painter, as well as memoirs, recollections, and a block of epistolary heritage requiring objective interpretationremainedoverlooked by scientists for a long time.

Among the existing studies worthy of a positive assessment, it is necessary to focus on the works of Gregory Kostyuk (1902-2002), who in the monograph Volodymyr Vynnychenko and his time. Research, criticism, controversy (1980) tries to reconstruct the ideological and artistic "image" of Vynnychenko. The researcher believes that either defending the national independence of Ukraine or solving national issues, he relied upon the idea of democratic development, which excludes any form of violent centralization, the dominance of one nation over another. The writer interpreted the concept of "national" in the dimensions of "universal."

It should be emphasized that the problem of the interaction "national - universal" is not as simple as Vynnychenko represented it. The text of the book Revival of the Nation (first edition: Vienna, 1920), on the pages of which he tried to restore and evaluate the events of 1917-1921 as an example of "unhappy" national history, also confirms it. The contradictory 
position of Vynnychenko himself did not allow objectivelyto answer the question: Can a nation be "happy" on a universal level being "unhappy" on a "national" level?

After Vynnychenko released the philosophical and political novel The New Commandment (1949) to the public, a polemic began, in which both the representatives of European literary criticism and a wide circle of Ukrainian emigration took part, namely: Taras Gunchak, Danylo Husar Struk, Ivan Lysyak-Rudnitsky, etc.

Works devoted to the analysis of the creative heritage of Volodymyr Vynnychenko performed by Vita Vinnik-Ostapishin, Tamara Gundorova, Nila Zborovskaya, and others start to appear in Ukrainein the late 1980s.

Paying tribute to all scholars whose works more or less relatedto the study of Vynnychenko's heritage, and despite the seemingly significant amount of research devoted to the analysis of the writer's heritage, we should note once again that some aspects of his work remain insufficiently studied and need to be in a thorough analysis. In our opinion, this concerns the phenomenon of the will as the element of moral and ethical searches of Vynnychenko, which, in their turn, relateto his concept of happiness as an imperative of the future.

\section{"Concepts of happiness" by Volodymyr Vynnychenko and Albert Schweitzer}

Volodymyr Vynnychenko being the author of a specific ethical concept basedon the idea of "eudaimonism," is the widely known fact.The writer stated this concept in his work Concordism ${ }^{l}$.The system of building happiness [Vynnychenko, 2011].

In the aforementioned work, written by Vynnychenko during 1938-1948, concordism was interpreted as a system of methods and rules for fighting the evil dominating humankind for a considerable part of its history. The writer saw a way out of this situation through asserting collective ownership. The latter should be based on collective morality represented in his 13 commandments. It is noteworthy that the concepts of "social" and "national" interconnected in Vynnychenko's ideas did not harmoniously unite in his own life, which complicated the situation of his moral choice and led to a personal drama.

The "commandments" requirea separate commentary; their essence is as follows: free from the "hypnosis" of religion; live by the fruits of your labor and in harmony with nature, with your instincts, mind, feelings, subconscious mind, and will; be honest with oneself and with others; to love freely, but to make a family only with the one you want to have children with; do not rule over others and do not allow others to rule over yourself; to be devoted to the collective [Vynnychenko, 2011].

To a certain extent, all these commandments echo the thoughts of ancient philosophers about the problem of the correlation between body and soul. The widely known fact is that for Socrates, the body is the flesh of the soul, and for the Epicureans it is self-identity. However, an intelligent person is not always spiritually mature, the intellectual is not always moral, and a literate person is not always decent. According to Aristotle, mental virtues contradict ethical (moral) ones since there is no act of will, which means love, will and intelligence are the only spiritual basis of human nature that contributes to the socialization of a person. One should note that an important aspect of the "concordism" theory was the comprehension of the ideas of Karl Marx, Friedrich Nietzsche, Sigmund Freud, Henri-Louis Bergson, and Jean-Marie Guyau within the context of the search for socio-psychological paths to happiness.

\footnotetext{
${ }^{1}$ Concordism - from lat. Concordia - consent, reconciliation.
} 
Proclaiming the ideas of "eudemonism" and "concordism" through the logic of the formation of his own moral concept, Vynnychenko, on the one hand, demonstrated knowledge of the theoretical position of European humanitarian thought, and on the other hand, "fit" into the moral searches of his contemporaries, doing this rather intuitively, since we were unable to find the names of the Ukrainian-Polish psychologist and literary critic Stefan Baley (18851952 ) and the German theologian, cultural philosopher Albert Schweitzer (1875-1965) in the works known to us.

In work From the Psychology of Shevchenko's Works (1916), Baley writes about eudemonism inherent in the work of the Ukrainian poet, artist, and thinker. "Daydreaming," "puerility," "contemplation," which, according to Baley, were inherent to Taras Shevchenko, can be found in the attitude of both Vynnychenko himself and the characters of his works.

As for Albert Schweitzer, in our opinion, there is no objection to the coincidence of the "concordism" model proposed by Vynnychenko with the moral search of a Protestant theologian, missionary, doctor, and musician. Schweitzer, in addition to his professional activities as a missionary, for which he received the Nobel Prize (1952), is widely known as the author of the concept of "reverence for life". Its main provisions -"worshipping" nature, the "principle of humanity" to the surrounding world — were "inspired" by the humanistic traditions of European ethics and transformed into the process of creating a "new ethical theory."

Vynnychenko's theory of "concordism" and Schweitzer's "new ethical theory" have much in common, but there are also differences. Therefore, both thinkers built their theories based on the concept of "will."

Under the concept of "will" Volodymyr Vynnychenko understood the conscious determination of a person to perform certain actions. Will is internal self-discipline, a person's ability to restrain passions, to organize emotions, to suppress anger, and to strive for perfection. The "will to excellence" is to characterize the activities of Vynnychenko most vividly both as a writer and as a political and public figure. Ultimately, the whole life and work of the writer provide a reason to argue that his moral position was the following belief: outside such a volitional aspiration, all possible virtues will be reduced exclusively to the contemplative activity of the mind.

Albert Schweitzer also argues about the "will," or rather, about the "will to live." By the concept of "will to live," the theoretician means a strive for perfection, for making ideals come true, the desire to achieve the highest material and spiritual value in ourselves and allentities subject to us. Out of this "value," on which rests everything that exists, "reverence for life" is born. The ethics of reverence for life includes not only the relationships between people but also the attitude towards everything that exists, i.e., according to Schweitzer, to nature as a whole: vegetation, living organisms, the global ocean, the earth. The latter echoes one of Vynnychenko's "commandments" as "to live in harmony with nature."

Both thinkers similarly interpreted the essence of such concepts as "individual ethics" and "public ethics," "individual morality" and "morality of society."

The main criterion for his morality Vynnychenko proclaims "honesty with oneself." Over time, the requirement to be "honest with oneself" will also be supplemented with the requirement to combine one's desires, caused by individual characteristics, with creative action within a certain community of people. He is convinced that a person must find their own path to happiness, avoiding wars and revolutions, and for this, one needs to change from the inside. In other words, harmonize individual ethics with public ethics. 
Albert Schweitzer expresses a similar idea: "Ethics, serving the interests of society, inherently means that society appeals to the consciousness of the individual to obtain from onewhat cannot impose by coercion and law.... Depending to what extent society accepts the character of a moral person, one's ethics becomes the ethics of a moral society" [Schweizer, 1992: 209]. At the same time, the German theoretician notes that ethics is a "sound gamut" including "the ethics of passive self-improvement by achieving internal liberation from the world (meek resignation), the ethics of active self-improvement by establishing a person's moral attitude to a man and the ethics of a moral society" [Schweizer, 1992: 209], where the "real ethics" is the "ethics of active self-improvement," that is, the ethics of a thinking, and, therefore, strong, personality.

For Volodymyr Vynnychenko, the opportunity to harmonize personal morality with public morality also indicates a strong personality. However, unlike Schweitzer, the Ukrainian writer believed that human consciousness and behavior are class-conditioned.Although this thesis is Marxist, many theoristsspoke about the conditioning of consciousness or behavior by the environment and social status, including Karl Eugen Dühring, who remarks: "The act of man has its basis in the character of the person and the social conditions in which he acts" [Dühring, 1896: 54-55]. Oddly enough, but many of the thoughts of the German theorist are reflected in the thoughts of the Ukrainian writer, or are embedded in the mouths of the characters created in the process of his literary activity. In particular, this concerns his thoughts about the morality of the dominant and oppressed, issues of honesty with oneself and the need for "balance."

Being a politician and citizen, Vynnychenko does not deny that ideology forms a kind of moral field, but the question still arises: what should give a moral quality to social being? And most importantly: what is the basis of human morality? For Dühring, the standards of labor morality, orderly life, moderation in lifestyle, loyalty to educational ideal determine the value of a person's life. Such understanding of the "value of life" is fully consistent with the judgment of Vynnychenko about the "will to moral choice." It should be noted that the works Disharmony (1905), Steps of Life (1907), (the novel Honesty with Oneself (1911) became its prosaic version), Memento (1908), Bazaar (1909), where gradually begins to develop the theme of "honesty", have the character of "moral provocations", which, as Larisa Levchuk notes, "is a reflection of the corresponding lifestyle and specifics of the writer's worldview," which was itself internally contradictory, "sometimes completely not even defined for himself" [Levchuk, 2011: 134]. Undoubtedly, these "moral provocations" could not but cause a flurry of criticism. It is interesting that the representatives of, so to speak, various "camps"criticized the writer, for instance: Ukrainophile Ivan Nechuy-Levitsky (1838-1918), a Russian writer close to the Social Democrats, financially supporting Bolshevism, Maxim Gorky (1868-1936), Ukrainian democrats of various movements, in particular, Sergiy Efremov (1876-1936), Symon Petliura (1879-1926), as well as numerous Ukrainian and Russian literary critics.

What meaning did Volodymyr Vynnychenko put in the concept of "honesty with oneself"? As he noted, this idea arose at a time when everyone who called oneself a revolutionary seemed to him a hero like Radishchev or Perovskaya. And then the future writer began to notice some disharmony between the surrounding real life and the images created by youthful imagination. Growing older, the writer saw this disharmony in himself. Moral searches of Vynnychenko interested in the problem of disharmony in human relationships, the correlation of truth and lies in the life of individual, the moral character of a revolutionary, the role and purpose of strong personalities, being the best according to the writer, whom he sometimes treats quite critically or sarcastically, lead to disappointment. Thus, Taras, one of the characters of the 
novel Honesty with oneself, turns to the revolutionary socialist Miron with a request: "I want to ask you to introduce me to the anarchists" [Vynnychenko, 1926a: 9-10]. Further it becomes clear that communists, socialists, as well as sharpers and prostitutes, belong to the anarchists. And for all these "anarchists," including prostitutes, it is necessary to create their trade unions with free access for everyone, including socialists.

Having discussed this problem, the underground members concluded that humanity, following the principle of "honesty with oneself," will finally come to a new life in which everyone will be equal: socialists, prostitutes, and sharpers. And this new life will be based on a new religion. What is this new religion? It is the religion of socialism.

Ironically, in the context of the problem of "honesty with oneself" the question of conscience is not raised.

Perhaps, since conscience is the chastity of the soul and the shame of the individual, a combination of duty and love, these feelings are not specific to Vynnychenko'scharacters. Thinking a lot about ethics, about morality, the writer's characters, perhaps, like himself, are in a certain confusion, no one knows how to overcome it. In other words, there is a will to moral searches, but there is no desire to decide for oneself the limits of moral and immoral within the will itself, since the new personality does not need it.

Arguably Vynnychenko's understanding of morality somewhat echoes reflections of Karl Eugen Dühring (The Value of Life) and Friedrich Nietzsche on the morality of the dominant clans and the enslaved (Human, all-too-Human), as well as relating to the concepts of "good" and "evil" for various layers of society. Thus, in the work Beyond Good and Evil, Nietzsche, in particular, expresses the following ideas: "There is an arrogance of kindness that has the appearance of malice" [Nietzsche, 2006: 634]. Volodymyr Vynnychenko, like Nietzsche, is inherent in reductionism. Building his concept of morality, the writer applies the following oppositions: good/evil, God/Devil, sanctity/sin. The same idea "sounds" in the writer's diary of March 27, 1929: "There is no desire to harm others in the world, there is only a desire to do good for yourself, which inevitably harms others. Without desiring good for oneself, there iseven no desire for evil for the enemy. A pure desire for one's good brings evil to others. Good and evil are one; they are like water:take a dropin one place, the whole basin will move" [Vynnychenko, 2012b: 57].

For Albert Schweitzer: "Good is what serves to preserve and develop life, evil is what destroys life or prevents it" [Schweizer, 1992: 218], and aggression or danger should be answered according to real circumstances: "To become moral means to become truly thinking," because "where I harm any life, I must clearly realize how necessary it is" [Schweizer, 1992: 223]. A moral person does not ask how much this or that life deserves his efforts; one does not ask whether it can and to what extent feel his kindness. Life is sacred for him as it is. He will not pick a leaf from a tree, will not break a single flower and will not crush a single insect since "ethics is a limitless responsibility for everything that lives" [Schweizer, 1992: 218]. Schweitzer claims the need to show equal reverence for life, both to one's will to live and to any other. In his opinion, this is the basic principle of morality.

Regarding spiritual love... The ability to love spiritually, not physically (or not only physically), characterizes certain deep ontological layers of the human self. Physical love characterizes only the carnal delight of a man, while spiritual love characterizes the inner world. As for Volodymyr Vynnychenko, then in him, so to speak, both of them were combined. Without dwelling on the details of the writer's personal life, it is worth noting that self-sacrifice as one of the highest manifestations of spiritual love was not peculiar to Vynnychenko's 
relations with women, the breakups with whom he explained with the idea of "honesty with oneself" (Lucy Goldmerstein), which deserves a separate study. In Ukrainian research, the history of relations between Volodymyr Vynnychenko and Lucy Goldmerstein, who gave birth to a writer's son, is rather widely known. The child was undesirablesince a short affair with this woman did not have much significance to Vynnychenko. The son died a few months later. As Larisa Levchuk notes, "the death of a child made a dramatic note in the relationship between Vynnychenko and Goldmerstein. At the same time, this life story had a somewhat unexpected continuation. In the fall of 1908, the twenty-eight-year-old Vynnychenko wrote the play Memento released in early 1909. The plot of the play, in fact, reflects the situation of the writer's relationship with Goldmerstein, but it includes an unexpected scene: the character of the play attempting to get rid of an unwanted child "exposes the baby to the cold and thereby provokes his death." Is this scene documentary? Could a young writerlose his illegitimate son like that? There is no evidence for a positive answer to these difficult questions; however, Lucy Goldmerstein and Vynnychenko's inner circle did not exclude just such a course of events" [Levchuk, 2011: 146-147].

In the work Volodymyr Vynnychenko: paradoxes of fate and oeuvre. The book of studies and travels, literary critic Volodymyr Panchenko notes that Goldmerstein, reading Memento, already had a suspicion that there was some connection between the ending of the play and the death of her child [Panchenko, 2004: 91]. It is also noteworthy that the writer uses this specific method of "attempting to kill" an unwanted child with cold air in the novel Notes of the SnubNosed Mephistopheles, in which the son of a famous Kyiv lawyer, fortunately, was not injured.

Therefore, the theme of sexual relations between a man and a woman is present in most of the writer's works and has, as a rule, a psychoanalytic "aftertaste." Another aspect of such relationships is the juxtaposition of feelings and reason. Vynnychenko's characters, like himself, asthe "Diaries" of the writer evidenced, reflect on the question: should the "new man" be guided by feelings or reason? The writer does not give a definite answer to this question, but the leitmotif of most of his works is a kind of cult, both instants of feelings and instants of love. This "instantness" of emotional or physical impulses iscontrasted to the "prevailing" morality, which seems to be something unnatural, producing disharmony in a person.

Albert Schweitzer adheres to a fundamentally different position, for which love is all-encompassingas it simultaneously includes compassion, joy, mutual aspiration and responsibility.

\section{Conclusion}

Summarizing the considered material, it is reasonable to draw the following conclusions:

1. The moral and ethical searches of Volodymyr Vynnychenko are based on the actualization of spiritual love, erotic and sexual relationships as a problem of happiness, self-improvement, as means of activating the moral principle of "honesty with oneself," as well as the desire for social justice, which in general give balance and harmony, which Vynnychenko so sought, connect a person with other people preserving one's freedom and individuality.

2. Among moral factors, "freedom" has special weight, since a person carries out and experiencesa volitional act - this is an act of one's own choice. The nature of the will lies in spirituality, its direct source is consciousness, but the will surpasses consciousness. "Released," in the sphere of practical activity, the will, in itself, 
becomes an autonomous and, therefore, a willful force. Hence, its goal is of particular importance.

3. Albert Schweitzer, unlike Volodymyr Vynnychenko, sought the highest philosophical truth, first of all, to realize it himself through the ethics of reverence for life, to achieve a spiritual connection with the Universe. For Schweitzer, to become moral means to become truly thinking, to do good for the afflicted is an internal need, the leitmotif of his whole life.

"Concordism" by Volodymyr Vynnychenko is also directed towards the future, however, if someone would try to use it as a "guide to action," it is more specific, tough and sociallyideologized compared to the Schweitzer's ideas.

\section{[ㅁ] References}

Dühring, Karl Eugen. The value of life. A study in the sense of heroic understanding. S.Peterburg: Tipografiya uchilishcha glukhonemykh, 1896: 345.

Kostyuk, Gregory. Volodymyr Vinnychenko and his era. Research, criticism, controversy. N'yu-York:Ukrayins'ka vil'na akademiya nauk SSHA, 1980.

Levchuk, Larisa. Ukrainian aesthetics: traditions and the current state. Kyiv: "Maklaut", 2011: 133-148.

Lotman, Yuri. Cleaat a crossroads. Ourlegacy. Moscow: Maxwell Communication Corporation Great Britain, 1988. V. 5.

Nietzsche, Friedrich. In Beyond Good and Evil. Moscow: Eksmo, 2006: 557-748.

Panchenko, Volodymyr. Volodymyr Vynnychenko: Paradoxes of Destiny and Creativity. Book of explorations and travels. Kyiv: Tvim inter, 2004.

Schweitzer, Albert. Blagogoveniye pered zhizn'yu. Moscow: Progress, 1992.

Vynnychenko, Volodymyr. Concordism. The system of building happiness. Kyiv: Ukrayins'kyypys'mennyk, 2011.

Vynnychenko, Volodymyr. Honesty with yourself. Writings. Kyiv: "Rukh”, Volume 16, 1926a. Vynnychenko, Volodymyr. Diary. Volume 4 (1929-1931). Kyiv: “Smoloskyp”, 2012b. 